\title{
EVALUATION OF PHYSICO-CHEMICAL, NUTRITIONAL AND MICROBIOLOGICAL QUALITY OF RAW COW'S MILK USUALLY CONSUMED IN THE CENTRAL PART OF CÔTE D'IVOIRE
}

Kra KAS ${ }^{1 *}$, Mégnanou RM¹, Akpa EE ${ }^{1}$, Assidjo NE², LS Niamké1

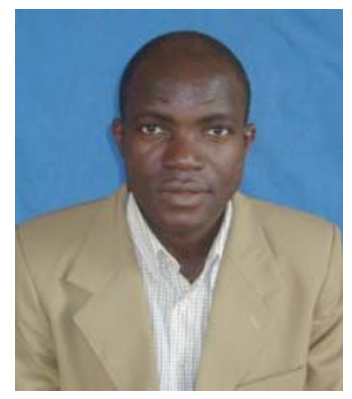

Kra Kouassi Séverin

*Corresponding author email: kra_severin@yahoo.fr

${ }^{1}$ Laboratory of Biotechnology, Félix Houphouet-Boigny University - Abidjan, 22 B. P. 582 Abidjan 22 (Côte d'Ivoire).

${ }^{2}$ Nutrition and Food Technology Laboratory, Direction of teaching and the research in chemical engineering and food processing, National Polytechnic institute Felix Houphouët Boigny (INP - HB) B.P. 1313 Yamoussoukro (Côte d'Ivoire). 


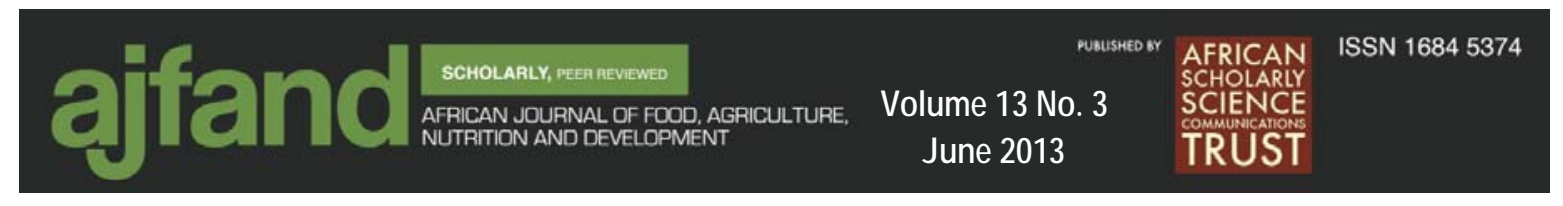

\section{ABSTRACT}

Cow's milk is by far the principal type of milk used throughout the world. Three systems of husbandry in Côte d'Ivoire produce raw milk. This production is always consumed directly by people, mainly children (orphans) although it presents real sanitary risks. In order to evaluate quality of these cow's milks, several samples were collected during a three month period (April to June 2009) at three cattle farms from where consumers got supplies. Physicochemical, nutritional, microbiological properties of the milks were studied. Results showed that viscosity, dry matter, fat and chloride contents of milk of traditional cows, N'dama and Zebu are higher than the standard values. $\mathrm{pH}$ values and acid content of N'dama milks are identical to those of standards. Zebu milk values for these two parameters are higher than standards: 6.59 $\pm 0.30>6.50 \pm 0.30 \% ; 21.0 \pm 1.0>17.0 \pm 1.0{ }^{\circ} \mathrm{D}$, respectively. However, conductivity, protein content, lactose and ash content of these milks are lower than those of standards. Comparing the characteristics of milks from various farms showed that farm $C$ had higher content of fat $(5.00 \pm 1.18>3.25 \pm 0.25)$, titrable acidity $(20.40 \pm 0.68>17.0 \pm 1.00)$, dry matter $(174.00 \pm 18.42>127.50 \pm 2.50)$, chloride $(2.66 \pm 0.56>1.60 \pm 0.20)$ and viscosity $(1.60 \pm 0.20>2.00 \pm 0.30)$ compared with the standard values. There is no significant difference $(p>0.05)$ in viscosity value, chloride and protein contents among the milks of the three farms. Conductivity, ash and protein content showed lower values than those of the standards. Microbiological result showed that all of the raw milks were contaminated, but the milks from farms B and C were more contaminated. Staphylococcus aureus count in milk of these farms were $8 \times 10^{2}$ and $65 \times 10^{2} \mathrm{cfu} / \mathrm{ml}, 5.1 \times 10^{5}$ and $251.2 \times 10^{5} \mathrm{cfu} / \mathrm{ml}$ for TVBC and total coliform were $3.85 \times 10^{3}$ and $6.91 \times 10^{3} \mathrm{cfu} / \mathrm{ml}$. These values are higher than those of the standards. In short, milk produced in the farms has acceptable physico-chemical, nutritional and properties but bad microbiological qualities.

Key words: raw milk, cows, quality, hygiene 


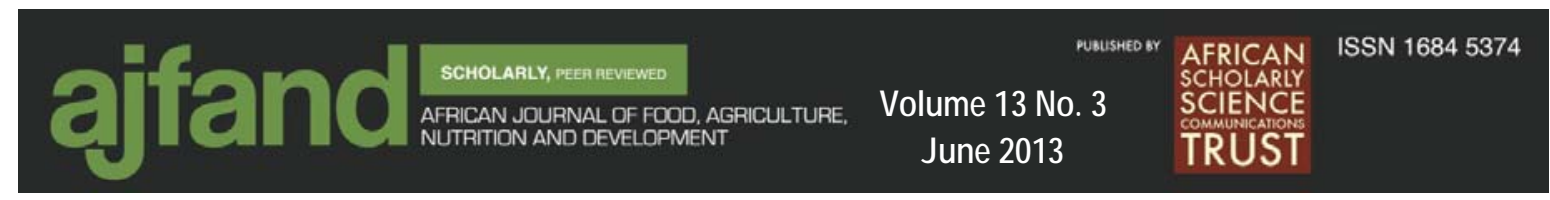

\section{INTRODUCTION}

Milk is one of the most common food sources in the human diet and is also a product that is directly available for consumption [1]. Its role is to nourish and provide immunological protection [2]. Milk has distinct physical, chemical and biological characteristics, which justifies its high quality for consumption. These characteristics present a favorable environment for the multiplication of various bacteria. It is well known that freshly obtained milk contains some bacteria and somatic cells, which represent the biological constituent of the milk [2]. According to Turner et al. [3], the biological constituents easily change depending on production conditions, the health status of the cattle, hygiene practices during milking, keeping and transportation of milk. The quality of milk as well as its safety in the consumption depends on its chemical composition, microbiological, physical and organoleptic properties. A satisfactory quality of milk means it is high in nutritional value and that it is free of any forms of bodies and of foreign constituents which can cause diseases [4].

In Côte d'Ivoire, milk is produced traditionally by three kinds of ranch systems: village sedentary system, which is a migrant system pursued by the Peulh (traditional ranch), the semi-modern system using crossbred cows with traditional treatment and the modern system according to Kra [5] and MINAGRA [6]. In the rural sectors, a study of Kra [5] showed that the current milk production cannot be sold due to lack of industrial market so that, the farmers send their production to local houses in which more inhabitants do not have milk in their diet. Most purchasers may not have good hygienic practice, so they consume raw milk without treatment. Unfortunately, because of poverty, this fresh milk is also given to infants, as well as orphans without suitable caution as revealed by Kra [5]. This poses a public health problem of food safety. In addition, physicochemical, nutritional and microbiological qualities of the milk from these three farms are unknown. This study's aim is to evaluate qualities of raw milk produced by cow species from the three farms in order to justify their consumption.

\section{MATERIALS AND METHODS}

\section{Milk sampling}

The study was conducted in Yamoussoukro (central region of Côte d'Ivoire) for three months, from May to July 2009. Three farms were used for this purpose. In the Modern farm coded A, there were crossbred cows (N'damon and N'damance) which benefited from appropriate treatment, sanitary follow-up and hygienic practices. Semi-modern farm coded B, contained the same type of crossbred cows as farm A, but, without follow-up and hygienic practices. The third farm was the traditional farm coded C. It contained local transhumant cows (N'dama and Zebu) without follow-up and hygienic practices. Samples were collected (early in the morning once a week every Wednesday) in sterile glass bottles either directly from the udder in the case of individual cows, or from the milk bulk tanks in the case of the mixture. These mixtures were done in the proportion $1 / 1(\mathrm{v} / \mathrm{v})$ if there are several tanks. Normal cows

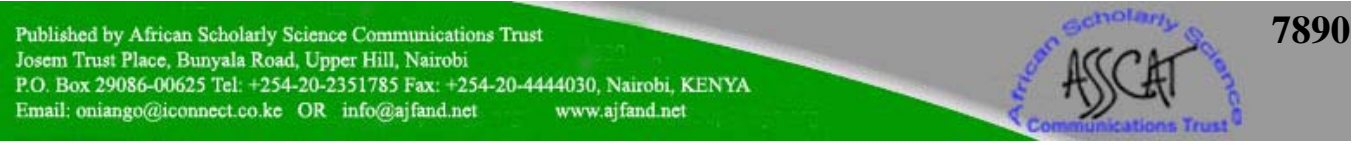




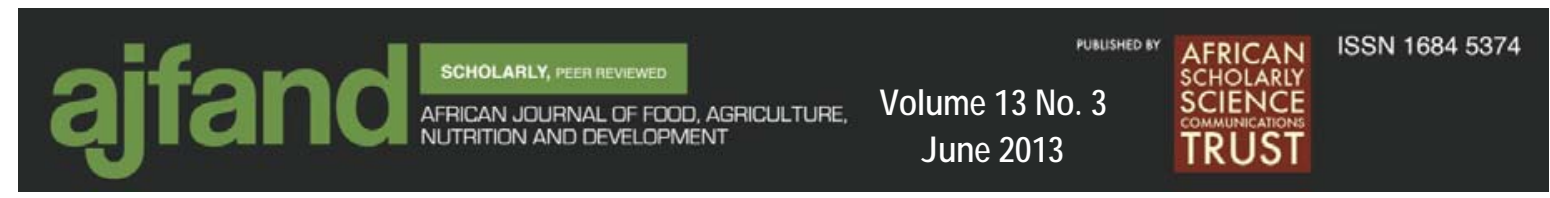

in second parturition were especially concerned. The milk was sampled and transported following NF V04-202 method [7].

\section{Physicochemical analysis}

Conductivity and viscosity were determined by the standard methods [8]. Total titrable acidity and $\mathrm{pH}$ value were determined according to method of AOAC [9]. Milk fat was determined according to NF V 04-210 [10]. Moisture, total solid (TS), total protein and ash contents were analyzed according to Ling [11]. Chloride content was determined according to Charpentier-Vohlard method described in NF V 04-212 [12]. Lactose content was determined according to Lane and Eynon method described in NF V 04-213 [13]. All analyses were performed at room temperature.

\section{Microbiology analysis}

The mixture of cow's raw milk samples $(11 \mathrm{ml})$ were homogenized during $1 \mathrm{~min}$ in $89 \mathrm{ml}(1 / 10)$ of sterile peptone solution $(0.1 \%$; w/v). From these samples serial decimal dilutions were prepared in $0.1 \%$ peptone solution. The microorganism counting was carried out by the pour-plate method with duplicate plating on different selective agar media according to Parrow [14].

Analyses procedures used were the following:

Total aerobic mesophilic bacteria were enumerated on Plate Count Agar after incubation in aerobic conditions at $30 \pm 1^{\circ} \mathrm{C}$ for $48 \mathrm{~h}$ and coliform counts were determined by the Violet Red Bile Agar with plate incubation at $35 \pm 2{ }^{\circ} \mathrm{C}$ for $48 \mathrm{~h}$ according to Dilielo [15]. The presumptive step was conducted with Lauryl Sulfate Tryptose broth $\left(35^{\circ} \mathrm{C}\right.$ for $\left.48 \mathrm{~h}\right)$ followed by the confirmation of total coliforms using Brilliant Green Bile broth $\left(35^{\circ} \mathrm{C}\right.$ for $\left.48 \mathrm{~h}\right)$. Thermotolerant coliforms were confirmed using Escherichia coli broth $\left(44.5^{\circ} \mathrm{C}\right.$ for $\left.48 \mathrm{~h}\right)$ and tryptone broth $\left(35^{\circ} \mathrm{C}\right.$ for $\left.48 \mathrm{~h}\right)$ followed by indole production detection.

Yeasts and molds were enumerated on Potato Dextrose Agar following the pour-plate method and incubated at $25^{\circ} \mathrm{C}$ for 5 - 7 days according to Koburger et al. [16]. The detection of Salmonella spp. and Staphylococcus aureus, was applied according to the methods described by FDA [17].

\section{STATISTICAL ANALYSIS}

Results were expressed as mean $\pm S D$ of three separate determinations. Data were statistically analyzed using the XLSTAT 2007 program. The significant differences between means were calculated by a one-way analysis of variance (ANOVA) using Duncan's multiple-range test at $\mathrm{p} \leq 0.05$.

\section{RESULTS}

Physicochemical and nutritional properties of each milk sample from cow species Table 1 shows various physicochemical parameters of the milk samples. Moisture contents of the milk samples were in the range of $82.86 \pm 1.68 \%$ to $86.80 \pm 1.68 \%$. The lowest value was found for N’Dama milk (82.86 $\pm 1.68 \%)$ and the highest value

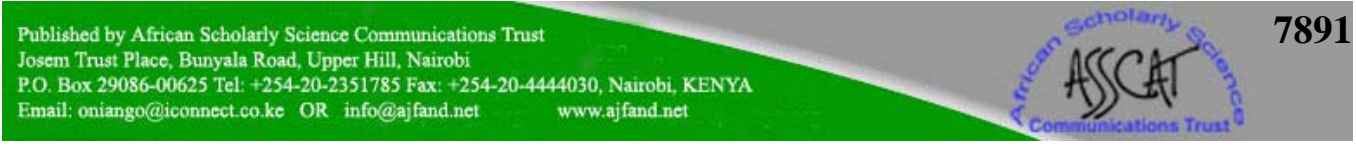




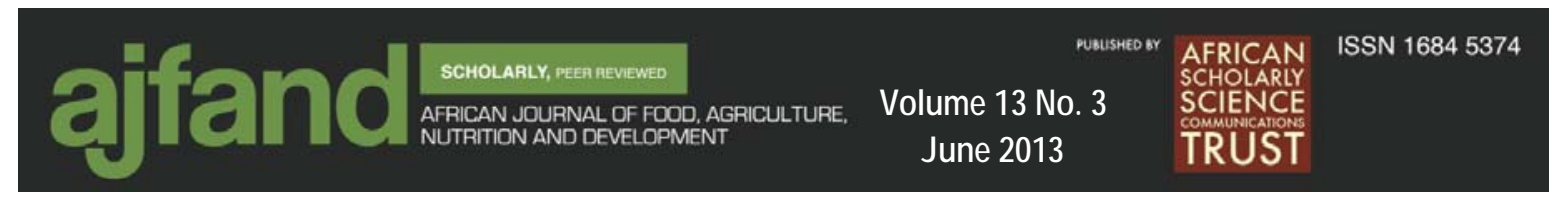

was shown by N'Damance milk (86.80 \pm 1.68$)$. Total solids content range of 13.70 $\pm 1.68 \%$ to $17.14 \pm 1.68 \%$. The lowest value was recorded for N'Damance milk $(13.70 \pm 1.68 \%)$ and the highest was shown by N'Dama milk $(17.14 \pm 1.68 \%)$. All these obtained values were significantly different at $5 \%$ level and higher than the standard ( $\mathrm{p}=0.0001)$. For the conductivity, values of all the milk samples ranged from $36.85 \pm 2.39 \Omega / \mathrm{cm}$ to $41.71 \pm 2.39 \Omega / \mathrm{cm}$. Minimum conductivity was recorded for the Zebu milk (36.85 $\pm 2.39 \Omega / \mathrm{cm}$ ) and maximum conductivity was measured for the N'Damance milk $(41.71 \pm 2.39 \Omega / \mathrm{cm})$. All values obtained are lower than those of standard. Viscosity values range between $2.15 \pm 0.06 \mathrm{cP}$ to $2.27 \pm 0.06 \mathrm{cP}$. There was no significant difference $(\mathrm{p}=0.0001)$ in N'Damon, N'Damance and standard values, as well as N'Dama and Zebu values which were higher than those of standard. Titrable acidity and $\mathrm{pH}$ values of all samples were found to be in the range from 18.10 $\pm 1.00{ }^{\circ} \mathrm{D}$ to $21.00 \pm 1.00{ }^{\circ} \mathrm{D}$ and $6.47 \pm 0.03{ }^{\circ} \mathrm{D}$ to $6.59 \pm 0.3{ }^{\circ} \mathrm{D}$, respectively. Titrable acidity lower value was registered for the N'Damance milk and the higher value for the Zebu milk.

Chloride contents of the milk samples were in the range of $0.25 \pm 0.02 \%$ to $0.28 \pm$ $0.02 \%$. There was no significant difference $(p>0.05)$ in N'Damon, N'Damance values, as well as those of N'Dama and Zebu which were higher. All these values were higher than those of standard. Reversely, lactose values obtained were lower than those of standard as showed in Table 2 . It was in the range of $2.73 \pm 0.24 \%$ to $3.43 \pm 0.24 \%$.

The amount of ash, fat and total proteins which were determined are presented in Table 2. Result shows that, as far as concerning the species, there is no significant difference $(p=0.0001)$ in ash content which is around $0.78 \pm 0.05 \%$. The nutritional properties of analyzed milks, except fat content, were lower than the standard values. Indeed, fat content ranges for $3.26 \pm 1.18 \%$ (for N'damon) to $6.50 \pm 1.18 \%$ (for N'dama). Protein contents of various species were twice lower than the standard value. They were in the range of $3.61 \pm 0.17 \%$ to $3.87 \pm 0.17 \%$.

\section{Physicochemical and nutritional properties of milks mixed from various farms}

In table 3 are presented the data obtained of milk mixture from cows of each farm. Total solids were in the range of $13.20 \pm 1.84 \%$ to $17.40 \pm 1.84 \%$. Modern and semimodern farms ((A) and (B)) have the lowest value, and the highest value was found for traditional farm (C). Conversely, the moisture content of milk sample is lower for farms $(\mathrm{A})$ and $(\mathrm{B})(82.60 \pm 1.73 \%)$ and higher for traditional farm $(\mathrm{C})(86.80 \pm 1.73$ $\%)$ which values were in consequence significantly different $(p<0.05)$ to the others. Total solids and moisture content obtained for milk mixture were similar with those found for cow species.

There is no significantly difference $(\mathrm{p}>0.05$ ) registered in conductivity, viscosity, $\mathrm{pH}$ and chloride content of milk mixture of the farms. However, chloride content is higher than the standard value $(0.27 \pm 0.05 \%>0.18 \pm 0.02 \%)$. These values are

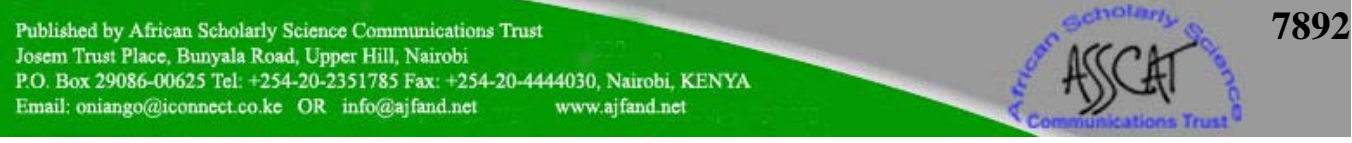




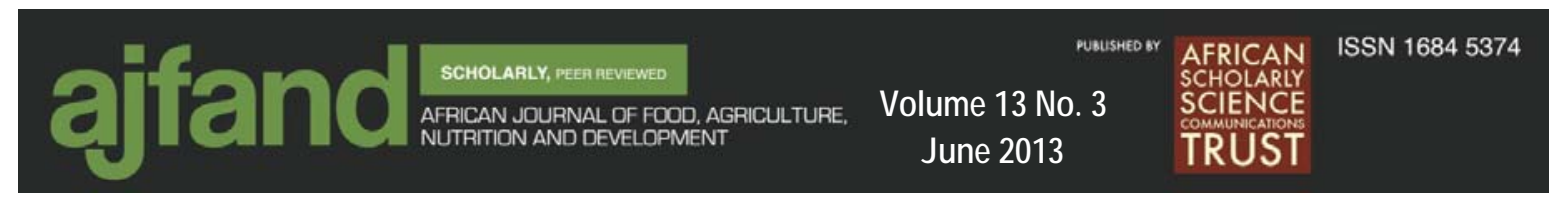

comparable with those obtained for cow species. Acidity of traditional farm (C) milk mixture is higher than the others $\left(21.1 \pm 0.68^{\circ} \mathrm{D}>20.5 \pm 0.68^{\circ} \mathrm{D}\right)$.

Table 4 presents results registered of nutritional characteristics of the milk mixture from each farm. Fat content ranged from $3.15 \pm 0.12 \%$ to $5.00 \pm 0.12 \%$ and data are statistically different at $5 \%$ level. The lower value was recorded in the semi-modern farm (B) (3.15 $\pm 0.12 \%)$ and the higher value was obtained in the traditional farm (C) $(6.00 \pm 0.12 \%)$. Lactose and protein values of these free farms were respectively lower than those of the standard $(2.85 \pm 0.17<4.95 \pm 0.15 \%)$ and $(3.90 \pm 0.14<4.00$ $\pm 0.10 \%)$ as it has already shown for the cow species. These values were not significantly different $(\mathrm{p}>0.05)$. Ash contents of milk mixture were in the range of $0.65 \pm 0.13 \%$ to $0.79 \pm 0.13 \%$. For the Farm (C), ash content is the higher and is not significantly different $(\mathrm{p}>0.05)$ to the standard value.

\section{Microbiological properties of milk mixed from various farms}

The microbiological analysis results of raw milk mixture are given in table 5. Data show that Salmonella spp were not detected in the milks. However, the number of total viable bacteria of milk in the three farms was higher than the recommended standard (251.2 (C) > 5.1 (B) > 3.55 (A) > $\left.3 \times 10^{5} \mathrm{cfu} / \mathrm{ml}\right)$. Thermotolerant coliforms, Yeasts, Molds and S. aureus counts were higher than standard value as follow : (5.1 (C) $>3.3$ (B) $>1.09$ (A) $\left.>1 \times 10^{2} \mathrm{cfu} / \mathrm{ml}\right) ;\left(28.04\right.$ (C) $>2.17$ (B) $\left.>1 \times 10^{3} \mathrm{cfu} / \mathrm{ml}\right)$; $\left(146.26\right.$ (C) $>2.94$ (B) $>2.8$ (A) $\left.>1 \times 10^{3} \mathrm{cfu} / \mathrm{ml}\right) ;\left(65\right.$ (C) $>8$ (B) $>3$ (A) $>1 \times 10^{2}$ $\mathrm{cfu} / \mathrm{ml})$. Only in the case of farm (A), total coliform count is lower than those of the standard $\left(0.423<1 \times 10^{3} \mathrm{cfu} / \mathrm{ml}\right)$. Coliform in milk of farm (C) and (B) $\left(6.91 \times 10^{3}\right.$ $\mathrm{cfu} / \mathrm{ml}$ and $\left.3.85 \times 10^{3} \mathrm{cfu} / \mathrm{ml}\right)$ were very high. All data were significantly different $(\mathrm{p}<$ $0.05)$.

\section{DISCUSSION}

Physicochemical and nutritional properties of each milk sample from cow species The moisture content registered of milk was close to those previously determined (80\% to $90 \%$ ) by Webb et al. [18] and Hassan [19]. In literature, the total solids in milk ranged from $10 \%$ to $17 \%$, which include fat and non-fat materials according to Webb et al. [18], Hassan [19] and [20]. The present results were in agreement with the reported literature.

On the other hand, high values of the conductivity would indicate an infection of udders. That is not the case in this study. Conductivity of the milk is mainly due to the presence of various electrolytes. René [21] reported that variation in conductivity may be due to the different levels of the electrolytes present in the milk samples.

The titrable acidity was found to be a bit higher than the reported standard [22, 23]. About $\mathrm{pH}$ value found in the current study was comparable with the findings in a previous investigation (6.38 \pm 0.60 to $6.77 \pm 0.88)$ according to Rehman and Salaria [22].

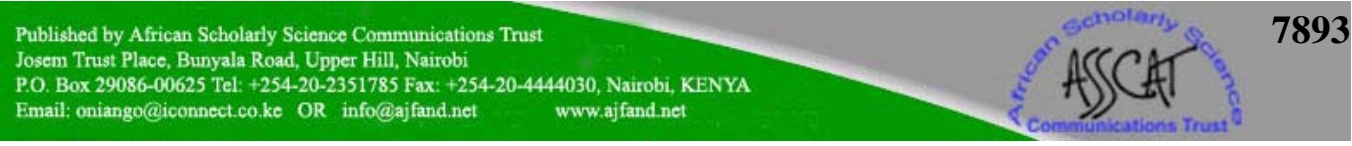




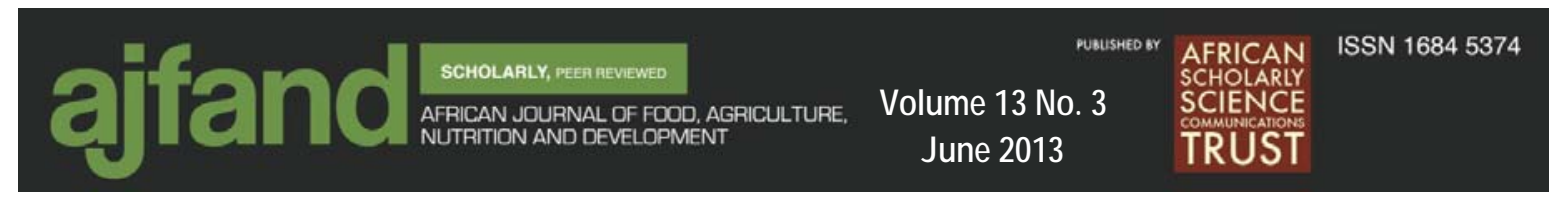

Lactose values obtained which were lower than the standard $(2.82 \pm 0.24 \%<3.43 \pm$ $0.24 \%<4.90 \pm 0.15 \%$ ) were justified by the higher content in chloride of milk according to René [21] and Pierre et al. [24]. Indeed, these authors reported that there is a narrow relation between the content of lactose of the milk and its content in chlorides. If the rate of chlorides is more raised, that of the lactose is lower. Chlorides content settles the osmotic balance of the secretion of the milk. The amount of ash, fat and total proteins which were obtained are in agreement with those reported by Séro [25]. Fat content showed that traditional fresh natural milk are richer source of fat than crossbred species one (N'Dama $6.50 \%$, Zebu $5.95 \%$, N'damance $3.36 \%$ and N'Damon $3.26 \%$ ). Such values for traditional cows in the range of 4.5 to $6.5 \%$ had been reported by Séro [25]. Cow's milk productions are weaker (0.4 to 1.2 liter per day) because of their long way running to get supply and their number of milking per day. This fact reduces moisture content of the milk and increase total solid through a higher fat content according to Neitz et al. [26] and René [27].

Total protein investigated (3.61 $\pm 0.17 \%$ to $3.87 \pm 0.17 \%$ ) was within the recommended values $2 \%$ to $4 \%$ for the total protein content of milk according to Webb et al. [18] and Hassan [19]. These results are also comparable with the literature. The lactose in the milk was from $2 \%$ to $5 \%$ as reported [18] and [19]. Results are also comparable with the literature. Ash contents (which highest value was $0.79 \pm 0.13 \%$ ) were lower than the standard but nevertheless, confirmed the strong content in total solids of milk. These values are in agreement with those obtained by Webb et al. [18] and Hassan [19] who reported that ash content was about $0.65 \%$.

\section{Microbiological properties of mixed milk from various farms}

Total viable bacterial, thermotolerants coliforms, yeasts, molds and S. aureus count of the mixed milk were higher than those of standard. Such value in several milk samples are found by Séro [25]. This prevalence of microorganism revealed that, raw milk produced particularly in the farm (C) and (B) have fairly poor quality. It would be due to mismanagement practices. Milkers might not adopt minimal standard hygiene such as wash their hands and cows' udders before milking. Also, milking might be made in a dirty and soiled environment of the cows. Such unhygienic practices which increase milk contamination by bacteria are observed in several farms in north Khartoum [28, 29]. Coliform group of bacteria in foods are accepted as unhygienic index [30]. Also, according to [31, 32, 33], raw milk is usually contaminated with coliform organisms. They are predominantly associated with the environment and unhygienic practices.

In the present study, Staphylococcus aureus prevalence in milk may originate from udder infection or contamination due to mismanagement practices such as poor milk system (hand milking). Earlier studies showed that this method does not only reflect infection but also the possible contamination of milk in its passage through the milking process [34, 35]. Comparable results were reported by [36, 37, 38, 39].

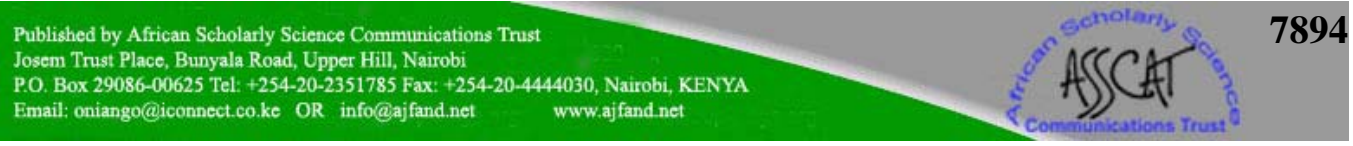




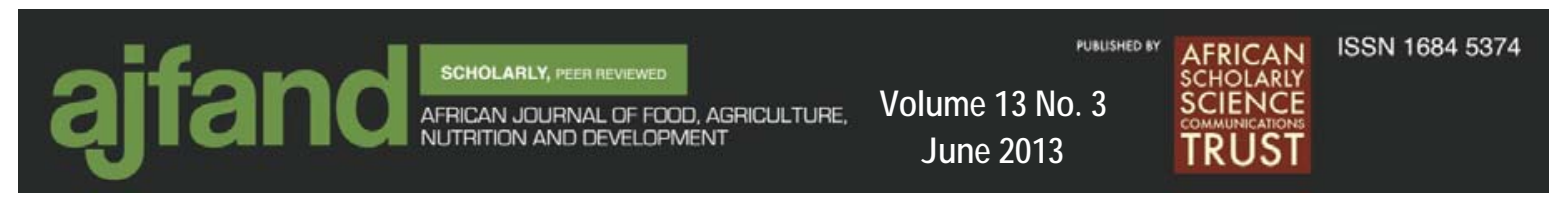

The high prevalence of microorganisms in the raw milk could be due to the fact that the herdsmen wash and wipe udders by using same cloth. This cloth was washed in the same water bucket and milkers usually clean their hands between milking by passing the hand through the same cloth [40]. The milking is usually executed in the same place, which is not clean and which is not separated. All these unhygienic conditions contribute a lot to increase the bacterial quantity before the milk reaches the milking buckets. These facts occur in farms (B) and (C). On the other hand, in the farm (A), the farmers were educated for dairy hygienic practices so that many cautions would be taken by milkers. That justifies lower content of microorganisms in milk of this farm than the others.

\section{CONCLUSION}

Results of this study revealed that traditional cows (Zébu and N'Dama) milk produce were richer in fat compared to the crossed races one's (N'Damon and N'Daman). This fact increases total solids and viscosity content in their milk. Also, fat content of milk had a significant effect on total solid and ash contents. However, lactose contents in the milk are weak, while the most important nutrient in milk for children is lactose because of the quantity of energy which it can supply. So, based on this fact, all the milks which were studied did not present ability for infant. Nevertheless, chemical properties, protein, fat and ash content results showed that these milks are required potentiality to be consumed by children. The real danger of these milks is their bacterial prevalence. Indeed, it was found that raw milks from farms (B) and (C) which had traditional dairy practices without trainings were very contaminated because of their high prevalence of Coliforms and Staphylococcus aureus. The bad milking process is known to cause poor hygienic quality of milks which become so unfit for consumption. This raises a real problem of public health. Urgent measures of raising awareness had to be applied by the Ministry of Health of Côte d'Ivoire such as informing or educating rural people that, it is necessary to treat milk before consumption in order to avoid serious sanitary problems. The Ministry of Agriculture and Animal Resources should enforce all the regulations needed for producing and purchasing raw milk with acceptable properties because it is a potentially dangerous food that must be processed and protected to assure its safety for humans. 


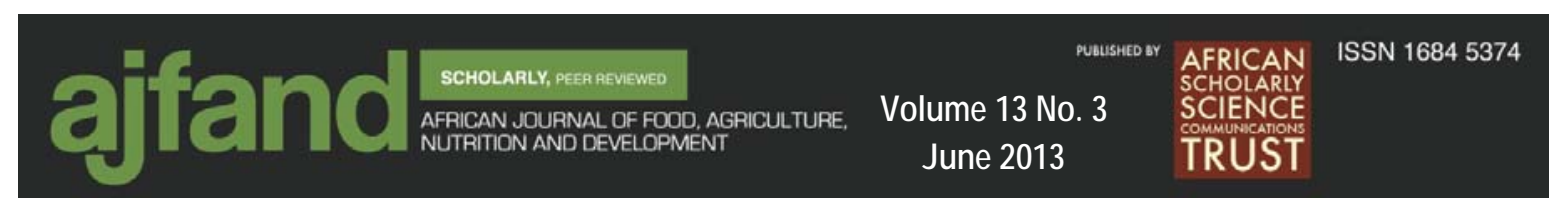

Table 1: Physicochemical properties of the milks from each cow

\begin{tabular}{|c|c|c|c|c|c|c|c|}
\hline Cow species & $\begin{array}{l}\text { Conductivity } \\
(\Omega / \mathrm{cm})\end{array}$ & $\begin{array}{l}\text { Viscosity } \\
\text { (cP) }\end{array}$ & $\begin{array}{l}\text { Moisture } \\
\text { content (\%) }\end{array}$ & $\begin{array}{l}\text { Total solid } \\
(\%)\end{array}$ & $\begin{array}{l}\text { Chloride } \\
\text { content (\%) }\end{array}$ & pH & $\begin{array}{l}\text { Acidity } \\
\left({ }^{\circ} \mathrm{D}\right)\end{array}$ \\
\hline Standard values & $45.00 \pm 5.00^{\mathrm{a}}$ & $2.15 \pm 0.15^{b}$ & $86.75 \pm 2.50^{\mathrm{a}}$ & $12.75 \pm 0.25^{\mathrm{e}}$ & $0.18 \pm 0.02^{\mathrm{d}}$ & $6.50 \pm 0.30^{\mathbf{b}}$ & $17.0 \pm 1.00^{\mathbf{b}}$ \\
\hline N'damon & $41.58 \pm 2.39^{c}$ & $2.15 \pm 0.06^{\mathrm{b}}$ & $85.76 \pm 1.68^{c}$ & $14.24 \pm 1.68^{c}$ & $0.25 \pm 0.02^{\mathbf{b}}$ & $6.49 \pm 0.3^{c}$ & $18.6 \pm 1.00^{\mathbf{b}}$ \\
\hline N'damance & $41.71 \pm 2.39^{c}$ & $2.16 \pm 0.06^{\mathrm{b}}$ & $86.31 \pm 1.68^{a}$ & $13.70 \pm 1.68^{d}$ & $0.25 \pm 0.02^{\mathbf{b}}$ & $6.47 \pm 0.3^{c}$ & $18.1 \pm 1.00^{\mathbf{b}}$ \\
\hline N'dama & $37.62 \pm 2.39^{d}$ & $2.26 \pm 0.06^{\mathbf{a}}$ & $82.86 \pm 1.68^{d}$ & $17.14 \pm 1.68^{\mathrm{a}}$ & $0.28 \pm 0.02^{\mathrm{a}}$ & $6.58 \pm 0.3^{\mathbf{a}}$ & $19.9 \pm 1.00^{\mathbf{a b}}$ \\
\hline Zébu & $36.85 \pm 2.39^{\mathrm{e}}$ & $2.27 \pm 0.06^{\mathbf{a}}$ & $83.68 \pm 1.68^{c}$ & $16.32 \pm 1.68^{\mathbf{b}}$ & $0.28 \pm 0.02^{\mathrm{a}}$ & $6.59 \pm 0.3^{\mathrm{a}}$ & $21.0 \pm 1.00^{\mathrm{a}}$ \\
\hline
\end{tabular}

The same letter $(a, b, c, d, e)$ in the same column indicated no statistical difference $(p \geq 0.05)$

The standard value represents the average value obtained from each characteristic according to FAO [41].

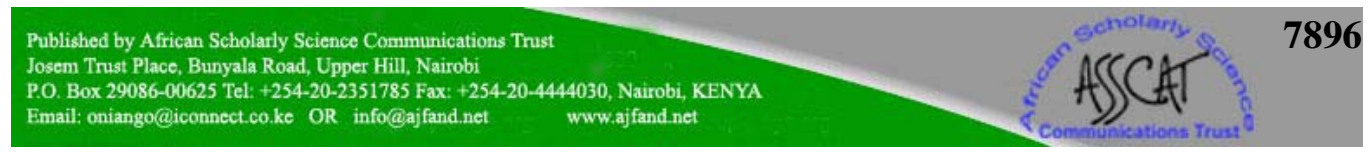




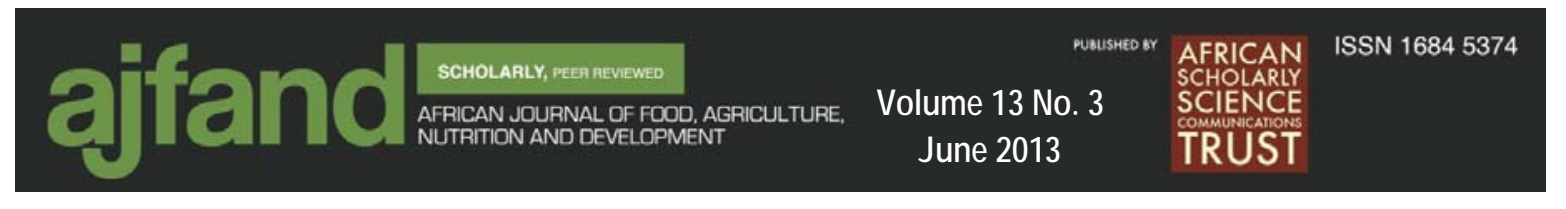

Table 2: Nutritional properties of the milks from each cow (\%)

\begin{tabular}{lcccc}
\hline Cow species & Ash content & Fat content & Lactose content & Protein content \\
\hline Standard values & $0.90 \pm 0.010^{\mathrm{a}}$ & $3.25 \pm 0.25^{\mathrm{d}}$ & $4.90 \pm 0.15^{\mathrm{a}}$ & $4.00 \pm 0.10^{\mathrm{a}}$ \\
N'damon & $0.78 \pm 0.05^{\mathrm{b}}$ & $3.26 \pm 0.18^{\mathrm{d}}$ & $3.43 \pm 0.24^{\mathrm{b}}$ & $3.87 \pm 0.17^{\mathrm{ab}}$ \\
$\mathbf{N}^{\prime}$ damance & $0.74 \pm 0.05^{\mathrm{b}}$ & $3.36 \pm 0.18^{\mathrm{d}}$ & $3.35 \pm 0.24^{\mathrm{b}}$ & $3.61 \pm 0.17^{\mathrm{c}}$ \\
$\mathbf{N}^{\prime}$ dama & $0.78 \pm 0.05^{\mathrm{b}}$ & $6.50 \pm 0.18^{\mathrm{a}}$ & $2.82 \pm 0.24^{\mathrm{c}}$ & $3.79 \pm 0.17^{\mathrm{b}}$ \\
Zébu & $0.75 \pm 0.05^{\mathrm{b}}$ & $5.95 \pm 0.18^{\mathrm{b}}$ & $2.73 \pm 0.24^{\mathrm{c}}$ & $3.82 \pm 0.17^{\mathrm{b}}$ \\
\hline
\end{tabular}

$\geq 0.05)$ 


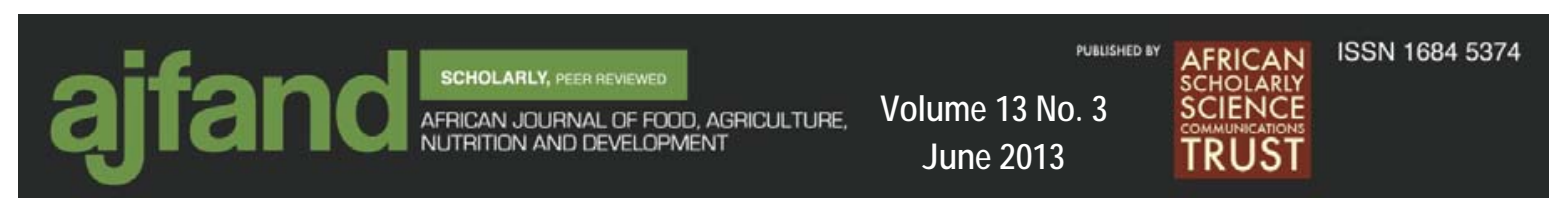

Table 3: Physicochemical properties of the mixed milk from various farms

\begin{tabular}{|c|c|c|c|c|c|c|c|}
\hline Farm & $\begin{array}{l}\text { Conductivity } \\
(10-4 \Omega / \mathrm{cm})\end{array}$ & $\begin{array}{l}\text { Viscosity } \\
\text { (cP) }\end{array}$ & $\begin{array}{l}\text { Moisture } \\
\text { content (\%) }\end{array}$ & $\begin{array}{l}\text { Total solid } \\
(\%)\end{array}$ & $\begin{array}{l}\text { Chloride } \\
\text { content (\%) }\end{array}$ & pH & $\begin{array}{l}\text { Acidity } \\
\left({ }^{\circ} \mathrm{D}\right)\end{array}$ \\
\hline A & $37.00 \pm 5.35^{\mathbf{b}}$ & $2.14 \pm 0.15^{\mathrm{a}}$ & $86.50 \pm 1.73^{a}$ & $13.50 \pm 1.84^{\mathbf{b}}$ & $0.26 \pm 0.05^{\mathbf{a}}$ & $6.50 \pm 0.22^{\mathrm{a}}$ & $20.50 \pm 0.68^{\mathbf{b}}$ \\
\hline C & $37.50 \pm 5.35^{\mathbf{b}}$ & $2.27 \pm 0.15^{\mathrm{a}}$ & $82.60 \pm 1.73^{\mathbf{b}}$ & $17.40 \pm 1.84^{\mathrm{a}}$ & $0.26 \pm 0.05^{\mathbf{a}}$ & $6.50 \pm 0.22^{\mathrm{a}}$ & $21.10 \pm 0.68^{\mathrm{a}}$ \\
\hline
\end{tabular}

The same letter $(a, b, c)$ in the same column indicated no statistical difference $(p \geq 0.05)$

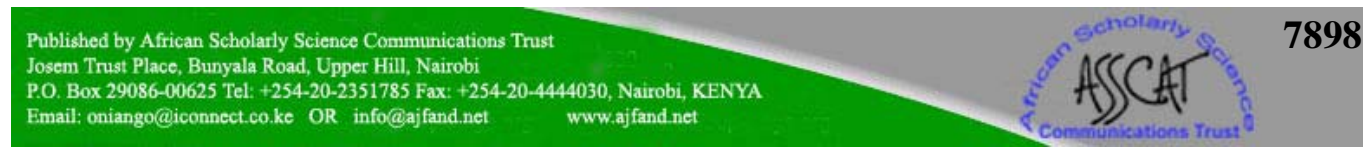


Table 4: Nutritional properties of the mixed milk from various farms (\%)

\begin{tabular}{lcclc}
\hline Farm & Ash content & Fat content & Lactose content & Protein content \\
\hline Standard values & $0.90 \pm 0.10^{\mathrm{a}}$ & $3.25 \pm 0.25^{\mathrm{c}}$ & $4.90 \pm 0.15^{\mathrm{a}}$ & $4.00 \pm 0.10^{\mathrm{a}}$ \\
A & $0.69 \pm 0.13^{\mathbf{b}}$ & $3.15 \pm 0.12^{\mathrm{c}}$ & $2.34 \pm 0.17^{\mathbf{b}}$ & $3.90 \pm 0.14^{\mathbf{b}}$ \\
B & $0.65 \pm 0.13^{\mathbf{c}}$ & $3.50 \pm 0.12^{\mathbf{b}}$ & $2.85 \pm 0.17^{\mathbf{b}}$ & $3.82 \pm 0.14^{\mathbf{b}}$ \\
C & $0.79 \pm 0.13^{\mathbf{a}}$ & $6.00 \pm 0.12^{\mathrm{a}}$ & $2.43 \pm 0.17^{\mathbf{b}}$ & $3.81 \pm 0.14^{\mathbf{b}}$ \\
\hline
\end{tabular}

The same letter $(a, b, c)$ in the same column indicated no statistical difference $(p \geq 0.05)$ 


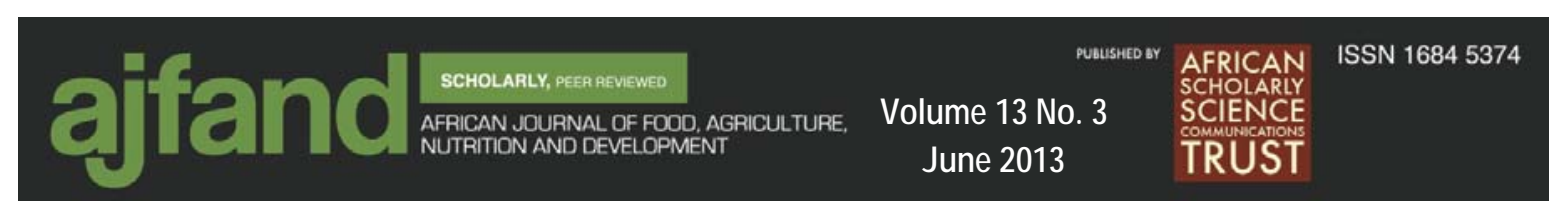

Table 5: Microbiology analysis of milk mixed from various farms (cfu/ml)

\begin{tabular}{|c|c|c|c|c|c|c|c|}
\hline Farm & $\begin{array}{l}\text { TVBC } \\
\left(\times 10^{5}\right)\end{array}$ & $\begin{array}{l}\text { Total Coliform } \\
\left(\mathrm{x10}^{3}\right)\end{array}$ & $\begin{array}{l}\text { Thermotolerant } \\
\text { Coliform }\left(\times 10^{2}\right)\end{array}$ & $\begin{array}{l}\text { Yeast } \\
\left(\mathbf{x 1 0}^{3}\right)\end{array}$ & $\begin{array}{l}\text { Mold } \\
\left(\mathbf{x 1 0}^{3}\right)\end{array}$ & $\begin{array}{l}\text { S. aureus } \\
\left({\left.\mathrm{x} 10^{2}\right)}^{2}\right.\end{array}$ & Salmonella \\
\hline Standard values & $<3$ & $<1$ & $<1$ & $<1$ & $<1$ & $<1$ & Absence \\
\hline A & $3.55^{c}$ & $0.423^{c}$ & $1.09^{c}$ & $1^{\mathrm{c}}$ & $2.8^{\mathrm{c}}$ & $3^{c}$ & Absence \\
\hline B & $5.1^{b}$ & $3.85^{\mathrm{a}}$ & $3.3^{\mathrm{b}}$ & $2.17^{\mathrm{b}}$ & $2.94^{\mathrm{b}}$ & $8^{\mathrm{b}}$ & Absence \\
\hline C & $251.2^{\mathrm{a}}$ & $6.91^{\mathrm{b}}$ & $5.1^{\mathrm{a}}$ & $28.04^{\mathrm{a}}$ & $146.26^{\mathrm{a}}$ & $65^{\mathrm{a}}$ & Absence \\
\hline
\end{tabular}

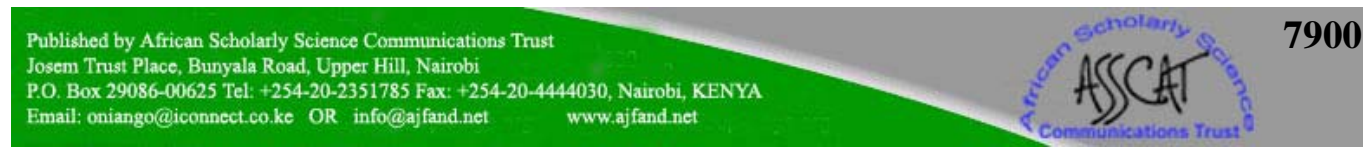




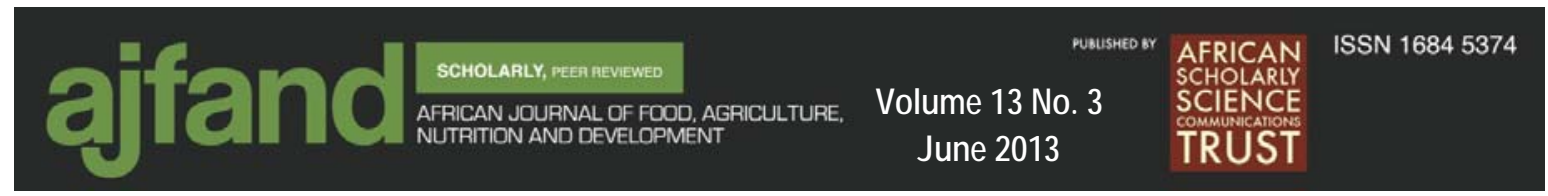

\section{REFERENCES}

1. Grimaud P, Sserunjogi $M$, Wesuta $M$, Grillet $N$, Kato $M$ and B Faye Effects of season and agro-ecological zone on the microbial quality of raw milk along the various levels of the value chain in Uganda. Tropic. Ani. Health Prod. 2009; 41: 883-890.

2. Hemalatha $\mathbf{S}$ and $\mathbf{S}$ Shanthi In vitro characterization of bacteriocin producing Bacillus subtilis from milk samples Afican J. Microbiol. Resea. 2010; 4(19): 2004 - 2010.

3. Turner GV and CM Veary Manual Onderstepoort: Food Hygiene. University of Pretoria 1990.

4. Ismail MM, Ammar EMA, El-Shazly AA and MZ Eid Impact of cold storage and blending different lactations of cow's milk on the quality of Domiati cheese. Afr. J. Food Sci. 2010; 4(8): 503 - 513.

5. Kra S Analyse qualitative du lait cru de vache de Côte d'Ivoire et sa coagulation par une enzyme végétale. Mémoire de DEA, Université de Cocody-Abidjan, Côte d’Ivoire 1998.

6. MINAGRA (Ministère de l'Agriculture et des Ressources Animales) Direction générale des ressources animales Projet national de développement du lait: identification. République de Côte d’ivoire pp 1 - 6 : 1999.

7. NF (Normes Françaises) V04-202 Juillet 1968. Echantillonnage en vue de l'analyse chimique et physique du lait In: Lait et produits laitiers, méthodes

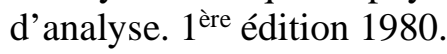

8. AOAC. Official methods of analysis. The association of official analytical chemists. 17th edition. Washington DC 2000.

9. AOAC. Official methods of analysis. The association of official analytical chemists. 16th edition. 481. North Fredrick Avenue Gaithersburg, Maryland, USA 2005.

10. NF (Normes Françaises) V 04-210 Septembre 1975. Determination de la matière grasse du lait - method acido-butyrique In: Lait et produits laitiers, méthodes d'analyse. $1^{\text {ère }}$ édition 1980.

11. Ling ER A text - book of Dairy Chemistry. Practical, $3^{\text {rd }}$ ed. 2: 36, Chapman and Hall, London, England 1963.

12. NF (Normes Françaises) V 04-212 Septembre 1969 Détermination de la teneur en chlorures du lait In: Lait et produits laitiers, méthodes d'analyse. $1^{\text {ère }}$ édition 1980. 


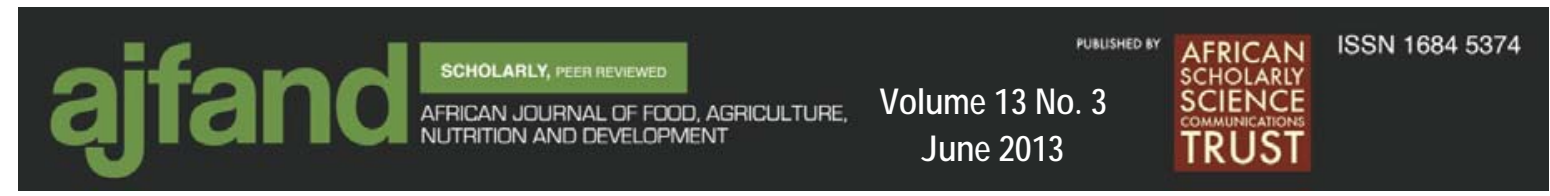

13. NF (Normes Françaises) V 04-213 Janvier 1971 Détermination de la teneur en lactose du lait In: Lait et produits laitiers, méthodes d'analyse. $1^{\text {ère }}$ édition 1980.

14. Parrow T Manual of Recommended Laboratory Methods for Sampling and Microbiological Testing of Single Service Food Packages and their Components. Syracuse, NY: Syracuse University Res. Corp. 1978.

15. Diliello LR Methods in food and dairy microbiology. Avi. Publishing Company Inc. USA p 142: 1982.

16. Koburger JA and EH Marth Yeast and Moulds. In: Marvin L. Speck (Editor), Compendium of Methods for the Examination of Foods APHA Washington DC USA 1984.

17. FDA. Bacteriological Analytical Manual. 8th ed. Revision A, Chapter. 4, 5, 10, 12 and 14. US Food and Drug Administration Center for Food Safety and Applied Nutrition, Gaithersburg: AOAC. International 1998.

18. Webb BH, Johnson AH and JA Alford Fundamental of Dairy Chemistry. $2^{\text {nd }}$ ed Chapter I. Westport, CT: AVI Publishing Co 1974.

19. Hassan SS Quality Assurance of Various Dairy Products. Pakistan: (MSc Thesis) Department of Chemistry, University of Peshawar 2005.

20. FAO. United Nations Food and Agriculture Organization: Statistics Yearbook Food and Agriculture Organization. FAO, Rome, Italy 1990.

21. René $\mathbf{R}$ Sciences et technologie du lait : principes et application. La fondation de technologie laitière du Québec, INC, Canada 1984.

22. Rehman ZU and AM Salaria Effect of storage conditions on the nutritional quality of UHT processed buffalo milk. J. Chem. Soc. Pak. 2005; 27(1): 7376.

23. Imran M, Khan H, Hassan SS and $\mathbf{R}$ Khan Physicochemical characteristics of various milk samples available in Pakistan. J.Dairy Sci. 2009; 92(9): 41354145.

24. Pierre D and C André Le contrôle pratique et industriel du lait. $6^{\text {ème }}$ édition. Editeurs J. B. Baillière et Fils, France 1951.

25. Séro K Lait et fromage au Bénin. Faculté des Sciences agronomique. Mémoire online 2005; webmaster@memoireonline.com

26. Neitz MH and NH Robertson Composition of milk and factors that influence it. Bulletin 421. Pretoria: Directorate of Agricultural Information, Department of Agriculture 1991. 


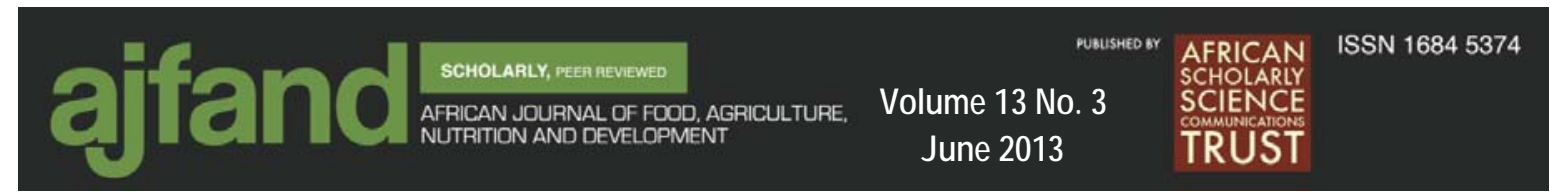

27. René M La connaissance du bétail: Les bovins. Collection d'enseignement agricole, J. B. Baillière et Fils, Tome 1 pp 77-134: 1983.

28. Egounléty M, Edema $\mathbf{M}$, Yehouessi $\mathbf{B}$ and $\mathbf{M}$ Ahouansou Production et qualité du fromage peuhl en République du Bénin. Rapport de Recherche, DNSA / FSA / UNB pp 30 - 33 : 1994.

29. Nuol AM, Atif EAG andMEJ Isam Host determinants of bovine mastitis in semi-intensive production system of Khartoum state, Sudan. J. of Cell and Ani. Bio. 2009; 3 (5): 071-077.

30. Salih Ö, Filiz $\mathbf{Y}$ and $\mathbf{O}$ Cihat Determination of microbiological characteristics of Turkish Karin Kaymagi cheeses packaged in different materials. Afr. J. Microbiol. Res. 2010; 4(9): 716-721.

31. Wessels D, Jooste PJ and JF Mostert Die voorkoms en betekenis van Enterobacteriaceae-isolate in melk en suiwel produkte. J. Dairy. Sci. 1988; 20(1): 23-28.

32. Boor KJ, Brown DP, Murphy SC, Kozlowski SM and DK Bandler Microbiological and chemical quality of raw milk in New York State. $J$. Dairy. Sci. 1998; 81(6): 1743-1748.

33. Murphy SC and KJ Boor Trouble-shooting sources and causes of high bacteria counts in raw milk. Dairy Food Environ. Sanitation 2000; 20(8): 606611.

34. Nyaga PN, Kagiko MM and JM Gathuma Milk hygiene in nomadic herds in Kenya evaluated by bacterial isolation and bacterial viability trials in traditionally fermenting milk and drug sensitivity. Bull. Anim. Hilth. Prod. Afr. 1982; 30:19-24.

35. Gonzalez RN, Jasper DE, Bushnell RB and TB Farver Relationship between mastitis pathogen number in bulk tank milk and bovine udder infection in a California dairy herd. J. Anim. Vet. Med. Asso. 1988; 189: 442445.

36. Elliot REW, Jeain GT and EO Brookbanks New Zealand National mastitis. The microflora of bovine composite milk samples. New Zeal. J. Vet. 1976; 24: 80-84.

37. El Tayeb A and N Habiballa Persistent mastitis in a dairy herd of a breeding centre. Sudan, J. Vet. Sci. Anim. Husb. 1978; 19: 96- 101.

38. Hinckely LS, Benson RH and JE Post How management affect the control of Staphylococcal mastitis. Dairy Sci. 1988: pp. 250-256. 


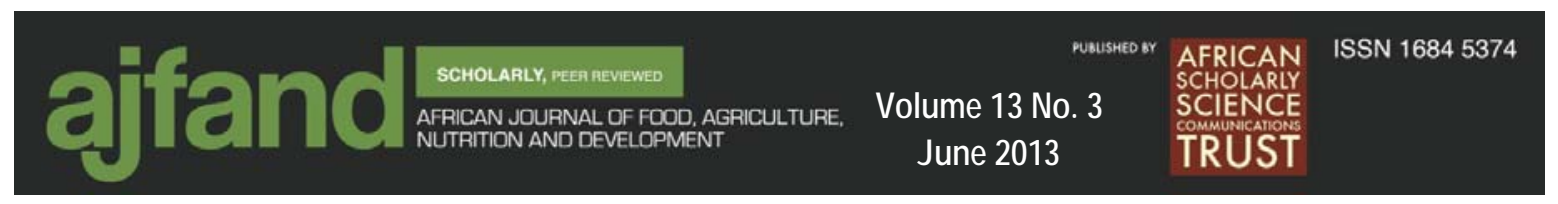

39. Zingeser J, Daye Y, Lopez V, Grant G, Bryan L, Kearney M and M Hugh-Jones National survey of clinical and sub clinical mastitis in Jamaican dairy herds. Trop. Anim. Husb. Hlth. Pro. 1991; 23: 2-10.

40. Adil MAS and ETM Tawfig Factors determining the load of Staphylococci species from raw bovine milk in Khartoum State, Khartoum North, Sudan. J. Cell Anim. Biol. 2010; Vol. 4 (1): 019-024.

41. FAO. Food and Agriculture Organization of the United Nations: Le lait et les produits laitiers dans la nutrition humaine Collection FAO: Alimentation et nutrition $n^{\circ} 28$, Rome, Italie 1978. 